удк 346.9

О. С. Алексєєва

\title{
ПРОБЛЕМНІ АСПЕКТИ ПРИМУСОВОГО ВИКОНАННЯ СУДОВИХ РІШЕНЬ ТА РІШЕНЬ ІНШИХ ОРГАНІВ (ПОСАДОВИХ ОСІБ) ЩОДО БОРЖНИКІВ, ДО ЯКИХ ЗАСТОСОВУЮТЬСЯ ПЕРСОНАЛЬНІ СПЕЦІАЛЬНІ ЕКОНОМІЧНІ ТА ІНШІ ОБМЕЖУВАЛЬНІ ЗАХОДИ (САНКЦІї)
}

Постановка проблеми. В Україні порядок проведення виконавчого провадження як завершальну стадію судового провадження та примусове виконання судових рішень та рішень інших органів (посадових осіб) (далі - рішення), які відповідно до Закону підлягають примусовому виконанню, визначає Закон України «Про виконавче провадження» від 02 червня 2016 р. № 1404-VIII [1] (далі - Закон).

Примусове виконання судових рішень є однією з ознак правової держави, в якій панує верховенство права та закону. У разі неналежного виконання чи невиконання судових рішень порушується право на справедливий та публічний судовий розгляд упродовж розумного строку. Крім того, фізичні та юридичні особи, витративши досить тривалий період часу на судовий розгляд справи, та не отримавши належного виконання відповідного рішення суду боржниками добровільно чи органом виконавчої служби у примусовому порядку, перестають довіряти судовій гілці влади, що є недопустимим у правовій державі, якою $е$ Україна.

Аналіз останніх досліджень та публікацій. Дослідження проблемних аспектів виконавчого провадження здійснювали такі дослідники як М.Й. Штефан, О.М. Ісаєнкова, В.О. Селезньова, Є.В. Мальцева, Ю.В. Бауліна та інші. Проте зазначені науковці досліджували питання щодо системи органів примусового виконання, статусу приватних виконавців в Україні та за кордоном.

Разом з тим на сьогодні питання стосовно примусового виконання рішень, де боржниками є фізичні та юридичні особи, до яких застосовуються персональні спеціальні економічні та інші обмежувальні заходи (санкцій), науковцями не досліджувалось.

Відтак, зазначене питання є проблемним, достатньо неврегульованим на законодавчому рівні та актуальним, яке необхідно детально вивчити та врегулювати на законодавчому рівні найближчим часом.

Саме тому метою та завданням цієї статті є здійснення аналізу чинного законодавства щодо примусового виконання рішень, у тому числі де боржниками є фізичні та юридичні особи, до яких застосовуються персональні спеціальні економічні та інші обмежувальні заходи (санкції), пошук ефективного механізму для примусового виконання таких рішень з метою його запровадження в Україні.

Виклад основного матеріалу дослідження. Відповідно до ст. 3 Закону примусовому виконанню підлягають рішення на підставі таких виконавчих документів:

- виконавчих листів та наказів, що видаються судами у передбачених законом випадках на підставі судових рішень, рішень третейського суду, рішень міжна- 
родного комерційного арбітражу, рішень іноземних судів та на інших підставах, визначених законом або міжнародним договором України;

- судових наказів;

- ухвал, постанов судів у цивільних, господарських, адміністративних справах, справах про адміністративні правопорушення, кримінальних провадженнях у випадках, передбачених законом;

- виконавчих написів нотаріусів;

- посвідчень комісій по трудових спорах, що видаються на підставі відповідних рішень таких комісій;

- постанов державних виконавців про стягнення виконавчого збору, постанов державних виконавців чи приватних виконавців про стягнення витрат виконавчого провадження, про накладення штрафу, постанов приватних виконавців про стягнення основної винагороди;

- постанов органів (посадових осіб), уповноважених розглядати справи про адміністративні правопорушення у випадках, передбачених законом;

- рішень інших державних органів та рішень Національного банку України, які законом визнані виконавчими документами;

- рішень Європейського суду з прав людини з урахуванням особливостей, які передбачені Законом України «Про виконання рішень та застосування практики Європейського суду з прав людини», а також рішень інших міжнародних юрисдикційних органів у випадках, які передбачені міжнародним договором України;

- рішень (постанов) суб'єктів державного фінансового моніторингу (їх уповноважених посадових осіб), якщо їх виконання за законом покладено на органи та осіб, які здійснюють примусове виконання рішень [1].

Таким чином, у ст. 3 Закону визначено вичерпний перелік виконавчих документів, на підставі яких рішення підлягають примусовому виконанню.

Разом з тим, вимоги до виконавчого документа передбачено у ст. 4 Закону.

Згідно з ч. 1 ст. 5 Закону примусове виконання рішень покладається на органи державної виконавчої служби (державних виконавців) та у передбачених цим Законом випадках на приватних виконавців, правовий статус та організація діяльності яких встановлюються Законом України «Про органи та осіб, які здійснюють примусове виконання судових рішень та рішень інших органів» .

До того ж ст. 6 Закону визначає, що у випадках, передбачених законом, рішення щодо стягнення майна та коштів виконуються органами доходів та зборів, а рішення щодо стягнення коштів - банками та іншими фінансовими установами. Рішення про стягнення коштів з державних органів, державного та місцевих бюджетів або бюджетних установ виконуються органами, що здійснюють казначейське обслуговування бюджетних коштів. У випадках, передбачених законом, рішення можуть виконуватися іншими органами. Зазначені органи та установи не $є$ органами примусового виконання [1].

Водночас заходами примусового виконання рішень відповідно до ст. 10 Закону є:

1) звернення стягнення на кошти, цінні папери, інше майно (майнові права), корпоративні права, майнові права інтелектуальної власності, об’єкти інтелектуальної, творчої діяльності, інше майно (майнові права) боржника, у тому числі 
якщо вони перебувають в інших осіб або належать боржникові від інших осіб, або боржник володіє ними спільно з іншими особами;

2) звернення стягнення на заробітну плату, пенсію, стипендію та інший дохід боржника;

3) вилучення в боржника та передача стягувачу предметів, які зазначені у рішенні;

4) заборона боржнику розпоряджатися та/або користуватися майном, яке належить йому на праві власності, у тому числі коштами, або встановлення боржнику обов'язку користуватися таким майном на умовах, визначених виконавцем;

5) інші заходи примусового характеру, передбачені цим Законом [1].

Отже, у ст. 10 Закону передбачено дії по примусовому виконанню рішень, які мають право вчиняти органи та установи, визначені у ст. ст. 5-6 Закону.

При цьому, згідно з ч. 1, 4 ст. 18 Закону державний (приватний) виконавець зобов'язаний вживати передбачені Законом заходи щодо примусового виконання рішень, неупереджено, ефективно, своєчасно та в повному обсязі вчиняти виконавчі діï. Вимоги державного (приватного) виконавця щодо виконання рішень $є$ обов'язковими на всій території України. Невиконання законних вимог виконавця тягне за собою відповідальність, передбачену законом.

Крім того, обов'язки та права державних (приватних) виконавців передбачено у ч. 2-3 ст. 18 Закону.

Разом $з$ тим, відповідно ч. 1,4 ст. 12 Закону виконавчі документи можуть бути пред'явлені до примусового виконання протягом трьох років, крім посвідчень комісій по трудових спорах та виконавчих документів, за якими стягувачем $є$ держава або державний орган, які можуть бути пред'явлені до примусового виконання протягом трьох місяців.

Строки пред’явлення виконавчого документа до виконання перериваються у разі:

1) пред'явлення виконавчого документа до виконання;

2) надання судом, який розглядав справу як суд першої інстанції, відстрочки або розстрочки виконання рішення [1].

Таким чином, ст. 12 Закону передбачає строк пред'явлення виконавчого документа до примусового виконання, що у загальному порядку становить три роки, крім посвідчень комісій по трудових спорах та виконавчих документів, за якими стягувачем є держава або державний орган, строк пред’явлення яких до примусового виконання становить 3 місяці.

При цьому, важливою є норма ч. 4 ст. 12 Закону, де передбачено, що у разі пред'явлення виконавчого документа до виконання строк пред'явлення виконавчого документа до виконання переривається.

Отже, у разі повернення виконавчого документа стягувачу, тобто отримання стягувачем виконавчого документа без виконання з підстав, встановлених ч. 1 ст. 37 Закону, строк пред'явлення виконавчого документа до виконання починається з початку з моменту отримання стягувачем оригіналу виконавчого документа.

Згідно з ч. 1-3 ст. 24 Закону виконавчі дії провадяться державним виконавцем за місцем проживання, перебування, роботи боржника або за місцезнаходженням його 
майна. Право вибору місця відкриття виконавчого провадження між кількома органами державної виконавчої служби, що можуть вчиняти виконавчі дії щодо виконання рішення на території, на яку поширюються їхні функції, належить стягувачу.

Приватний виконавець приймає до виконання виконавчі документи за місцем проживання, перебування боржника-фізичної особи, за місцезнаходженням боржника-юридичної особи або за місцезнаходженням майна боржника. Виконавчі дії у виконавчих провадженнях, відкритих приватним виконавцем у виконавчому окрузі, можуть вчинятися ним на всій території України.

Виконання рішення, яке зобов’язує боржника вчинити певні дії, здійснюється державним (приватним) виконавцем за місцем вчинення таких дій [1].

У ч. 1 ст. 26 Закону передбачено, що державний (приватний) виконавець розпочинає примусове виконання рішення на підставі виконавчого документа, зазначеного у ст. 3 Закону:

1) за заявою стягувача про примусове виконання рішення;

2) за заявою прокурора у разі представництва інтересів громадянина або держави в суді;

3) якщо виконавчий документ надійшов від суду у випадках, передбачених законом;

4) якщо виконавчий документ надійшов від суду на підставі ухвали про надання дозволу на примусове виконання рішення іноземного суду (суду іноземної держави, інших компетентних органів іноземної держави, до повноважень яких належить розгляд цивільних чи господарських справ, іноземних чи міжнародних арбітражів) у порядку, встановленому законом;

5) у разі якщо виконавчий документ надійшов від Національного агентства України з питань виявлення, розшуку та управління активами, одержаними від корупційних та інших злочинів [1].

Отже, наявність виконавчого документа не є підставою для примусового виконання судового рішення. У більшості випадків необхідна заява стягувача, а також сплата авансового внеску. Вимоги щодо сплати авансового внеску та випадки звільнення від його сплати встановлено у ч. 2 ст. 26 Закону.

Випадки, коли виконавче провадження підлягає закінченню, та наслідки закінчення виконавчого провадження, повернення виконавчого документа передбачено у ст.ст. 39-40 Закону.

Враховуючи викладене, Закон містить необхідні норми, що застосовуються при примусовому виконанні судових рішень та рішень інших органів (посадових осіб), які відповідно до Закону підлягають примусовому виконанню.

Водночас, що стосується виконання судових рішень шляхом накладення арешту на кошти та майно боржників, що є у переліку фізичних (юридичних) осіб, до яких застосовуються обмежувальні заходи (санкції) відповідно до Закону України «Про санкції», то зазначаємо наступне.

Враховуючи ст. 10 Закону, де передбачено заходи примусового виконання рішення, у п. 7 ч. 3-6 ст. 18 Закону визначено, що державний (приватний) виконавець під час здійснення виконавчого провадження має право накладати арешт на кошти та інші цінності боржника, зокрема на кошти, які перебувають у касах, 
на рахунках у банках, інших фінансових установах та органах, що здійснюють казначейське обслуговування бюджетних коштів (крім коштів на рахунках платників у системі електронного адміністрування податку на додану вартість, коштів на рахунках зі спеціальним режимом використання, спеціальних та інших рахунках, звернення стягнення на які заборонено законом), на рахунки в цінних папеpax, а також опечатувати каси, приміщення та місця зберігання грошей [1].

Відповідно до ч. 2-3 ст. 48 Закону стягнення за виконавчими документами звертається в першу чергу на кошти боржника у національній та іноземній валютах, інші цінності, у тому числі на кошти на рахунках боржника у банках та інших фiнансових установах.

На кошти та інші цінності боржника, що перебувають на рахунках та на зберіганні у банках чи інших фінансових установах, на рахунках у цінних паперах у депозитарних установах, накладається арешт не пізніше наступного робочого дня після їх виявлення. Арешт поширюється також на кошти на рахунках, відкритих після винесення постанови про накладення арешту.

У разі відсутності у боржника коштів та інших цінностей, достатніх для задоволення вимог стягувача, стягнення невідкладно звертається також на належне боржнику інше майно, крім майна, на яке згідно із законом не може бути накладено стягнення. Звернення стягнення на майно боржника не зупиняє звернення стягнення на кошти боржника. Боржник має право запропонувати види майна чи предмети, які необхідно реалізувати в першу чергу. Черговість стягнення на кошти та інше майно боржника остаточно визначається виконавцем.

Стягнення на майно боржника звертається в розмірі та обсязі, необхідних для виконання за виконавчим документом, з урахуванням стягнення виконавчого збору, витрат виконавчого провадження, штрафів, накладених на боржника під час виконавчого провадження, основної винагороди приватного виконавця. У разі якщо боржник володіє майном разом з іншими особами, стягнення звертається на його частку, що визначається судом за поданням виконавця [1].

Таким чином, Законом визначена процедура накладення арешту на кошти та майно боржника.

Відповідно до ст. 1072 Цивільного кодексу України від 16 січня 2003 р. № 435-IV [2] банк виконує розрахункові документи відповідно до черговості їх надходження та виключно в межах залишку грошових коштів на рахунку клієнта, якщо інше не встановлено договором між банком та клієнтом.

У разі одночасного надходження до банку кількох розрахункових документів, на підставі яких здійснюється списання грошових коштів, банк списує кошти з рахунку клієнта у такій черговості:

1) у першу чергу списуються грошові кошти на підставі рішення суду для задоволення вимог про відшкодування шкоди, завданої каліцтвом, іншим ушкодженням здоров'я або смертю, а також вимог про стягнення аліментів;

2) у другу чергу списуються грошові кошти на підставі рішення суду для розрахунків щодо виплати вихідної допомоги та оплати праці особам, які працюють за трудовим договором (контрактом), а також виплати за авторським договором;

3) у третю чергу списуються грошові кошти на підставі інших рішень суду; 
4) у четверту чергу списуються грошові кошти за розрахунковими документами, що передбачають платежі до бюджету;

5) у п'яту чергу списуються грошові кошти за іншими розрахунковими документами в порядку їх послідовного надходження.

У разі одночасного надходження до банку розрахункового документа, наданого відповідно до умов обтяження, предметом якого є майнові права на грошові кошти, що знаходяться на банківському рахунку, та іншого розрахункового документа, на підставі якого здійснюється списання грошових коштів, банк списує кошти 3 рахунка клієнта позачергово за розрахунковим документом, наданим відповідно до умов такого обтяження. У разі одночасного надходження до банку декількох розрахункових документів, наданих відповідно до умов обтяжень, предметом яких $€$ майнові права на грошові кошти, що знаходяться на банківському рахунку, банк списує кошти з рахунка клієнта за такими розрахунковими документами згідно з пріоритетом відповідних обтяжень.

У разі відсутності (недостатності) грошових коштів на рахунку клієнта банк не веде обліку розрахункових документів, якщо інше не встановлено договором між банком та клієнтом [2].

Разом з тим, на даний час до багатьох фізичних та юридичних осіб застосовуються персональні спеціальні економічні та інші обмежувальні заходи (санкцій) відповідно до ст. 4 Закону України «Про санкції» від 14 серпня 2014 р. № 1644-VII [3], а саме:

1) блокування активів - тимчасове обмеження права особи користуватися та розпоряджатися належним їй майном;

2) обмеження торговельних операцій;

3) обмеження, часткове чи повне припинення транзиту ресурсів, польотів та перевезень територією України;

4) запобігання виведенню капіталів за межі України;

5) зупинення виконання економічних та фінансових зобов'язань;

6) анулювання або зупинення ліцензій та інших дозволів, одержання (наявність) яких є умовою для здійснення певного виду діяльності, зокрема, анулювання чи зупинення дії спеціальних дозволів на користування надрами;

7) заборона участі у приватизації, оренді державного майна резидентами іноземної держави та особами, які прямо чи опосередковано контролюються резидентами іноземної держави або діють в їх інтересах;

8) заборона користування радіочастотним ресурсом України;

9) обмеження або припинення надання телекомунікаційних послуг та використання телекомунікаційних мереж загального користування;

10) заборона здійснення державних закупівель товарів, робіт та послуг у юридичних осіб - резидентів іноземної держави державної форми власності та юридичних осіб, частка статутного капіталу яких знаходиться у власності іноземної держави, а також державних закупівель у інших суб'єктів господарювання, що здійснюють продаж товарів, робіт, послуг походженням з іноземної держави, до якої застосовано санкції згідно з цим Законом;

11) заборона або обмеження заходження іноземних невійськових суден та військових кораблів до територіального моря України, її внутрішніх вод, портів та 
повітряних суден до повітряного простору України або здійснення посадки на території України;

12) повна або часткова заборона вчинення правочинів щодо цінних паперів, емітентами яких є особи, до яких застосовано санкції згідно з цим Законом;

13) заборона видачі дозволів, ліцензій Національного банку України на здійснення інвестицій в іноземну державу, розміщення валютних цінностей на рахунках та вкладах на території іноземної держави;

14) припинення видачі дозволів, ліцензій на ввезення в Україну з іноземної держави чи вивезення з України валютних цінностей та обмеження видачі готівки за платіжними картками, емітованими резидентами іноземної держави;

15) заборона здійснення Національним банком України реєстрації учасника міжнародної платіжної системи, платіжною організацією якої є резидент іноземної держави;

16) заборона збільшення розміру статутного капіталу господарських товариств, підприємств, у яких резидент іноземної держави, іноземна держава, юридична особа, учасником якої є нерезидент або іноземна держава, володіє 10 та більше відсотками статутного капіталу або має вплив на управління юридичною особою чи іï діяльність;

17) запровадження додаткових заходів у сфері екологічного, санітарного, фітосанітарного та ветеринарного контролю;

18) припинення дії торговельних угод, спільних проектів та промислових програм у певних сферах, зокрема у сфері безпеки та оборони;

19) заборона передання технологій, прав на об'єкти права інтелектуальної власності;

20) припинення культурних обмінів, наукового співробітництва, освітніх та спортивних контактів, розважальних програм з іноземними державами та іноземними юридичними особами;

21) відмова в наданні та скасування віз резидентам іноземних держав, застосування інших заборон в'їзду на територію України;

22) припинення дії міжнародних договорів, згода на обов'язковість яких надана Верховною Радою України;

23) анулювання офіційних візитів, засідань, переговорів з питань укладення договорів чи угод;

24) позбавлення державних нагород України, інших форм відзначення;

25) інші санкції, що відповідають принципам іх застосування, встановленим цим Законом [3].

Зазначені персональні спеціальні економічні та інші обмежувальні заходи (санкції) застосовано до відповідних фізичних та юридичних осіб на підставі:

- Указу Президента України від 15 березня 2017 року № 63/2017 [4], яким введено в дію рішення Ради національної безпеки та оборони України від 15 березня 2017 р. «Про застосування персональних спеціальних економічних та інших обмежувальних заходів (санкцій)» стосовно застосування персональних спеціальних економічних та інших обмежувальних заходів (санкцій) до юридичних осіб згідно з додатком; 
- Указу Президента України від 15 травня 2017 року № 133/2017 [5], яким введено в дію рішення Ради національної безпеки та оборони України від 28 квітня 2017 р. «Про застосування персональних спеціальних економічних та інших обмежувальних заходів (санкцій)» стосовно застосування персональних спеціальних економічних та інших обмежувальних заходів (санкцій) до фізичних осіб згідно 3 додатком 1 та до юридичних осіб згідно з додатком 2 ;

- Указу Президента України від 06 березня 2018 року № 57/2018 [6], яким введено в дію рішення Ради національної безпеки та оборони України від 01 березня 2018 р. «Про застосування персональних спеціальних економічних та інших обмежувальних заходів (санкцій)» стосовно застосування персональних спеціальних економічних та інших обмежувальних заходів (санкцій) до юридичних осіб згідно з додатком;

- Указу Президента України від 14 травня 2018 року № 126/2018 [7], яким введено в дію рішення Ради національної безпеки та оборони України від 02 травня 2018 р. «Про застосування персональних спеціальних економічних та інших обмежувальних заходів (санкцій)» стосовно застосування персональних спеціальних економічних та інших обмежувальних заходів (санкцій) до фізичних осіб згідно 3 додатком 1 та до юридичних осіб згідно з додатком 2 ;

- Указу Президента України від 21 червня 2018 року № 176/2018 [8], яким введено в дію рішення Ради національної безпеки та оборони України від 21 червня 2018 р. «Про застосування та внесення змін до персональних спеціальних економічних та інших обмежувальних заходів (санкцій)» стосовно застосування персональних спеціальних економічних та інших обмежувальних заходів (санкцій) до фізичних осіб згідно з додатком 1 та до юридичних осіб згідно з додатком 2.

Постановою Правління Національного банку України від 01.10.2015 № 654 (у редакції станом на 03 липня 2018 р.) «Про забезпечення реалізації та моніторингу ефективності персональних спеціальних економічних та інших обмежувальних заходів (санкцій)» (далі - Постанова № 654) [9] визначено механізм реалізації банками України та небанківськими установами санкцій щодо осіб, перелік яких зазначено у додатках до рішень Ради національно безпеки та оборони України по застосуванню персональних спеціальних економічних та інших обмежувальних заходів (санкцій). Зокрема, підпунктами 3-8 пункту 1, пунктами 2 та 3 постанови № 654 визначені обов'язки та особливості дій фінансових установ під час проведення фінансових операцій за участю осіб, зазначених в санкційних списках.

У більшості випадків строк застосування таких санкцій становить 3 роки/безстроково.

Разом 3 тим, у Постанові № 654 не визначено механізм яким чином державним (приватним) виконавцям здійснювати звернення стягнення на кошти боржників згідно зі ст. 48 Закону України «Про виконавче провадження», а банківським установам здійснювати списання грошових коштів відповідно до ст. 1072 Цивільного кодексу України, до яких застосовані персональні спеціальні економічні та інші обмежувальні заходи (санкціі), оскільки, як зазначалось вище, строк пред'явлення виконавчого документа до примусового виконання у загальному порядку становить три роки (ст. 12 Закону). 
Згідно з п. 1 Положення про Міністерство юстиції України, затверджене постановою Кабінету Міністрів України від 02 липня 2014 р. № 228 (далі - Положення) [10] Міністерство юстиції України є головним органом у системі центральних органів виконавчої влади, що забезпечує формування та реалізує державну правову політику, зокрема державну політику організації примусового виконання рішень судів та інших органів (посадових осіб).

У п. 3 Положення передбачено, що основними завданнями Міністерства юстиції України, зокрема, є:

- забезпечення формування та реалізація державної політики у сфері організації примусового виконання рішень;

- забезпечення своєчасного, повного та неупередженого виконання рішень у порядку, встановленому законодавством [10].

Водночас, що стосується примусового виконання рішень, то Міністерство юстиції України відповідно до покладених на нього завдань (п. 4 Положення) організовує, контролює та здійснює примусове виконання рішень у випадках, передбачених законом; надає державним та приватним виконавцям роз'яснення та рекомендації з питань примусового виконання рішень, забезпечує контроль за роботою структурних підрозділів територіальних органів Міністерства юстиції України, що забезпечують здійснення повноважень у сфері примусового виконання рішень тощо.

В той самий час відповідно до ст. 2 Закону України «Про національний банк України» від 20 травня 1999 р. № 679-XIV [11] Національний банк України $є$ центральним банком України, особливим центральним органом державного управління, юридичний статус, завдання, функції, повноваження та принципи організації якого визначаються Конституцією України, цим Законом та іншими законами України.

Згідно із Законом України «Про засади державної регуляторної політики у сфері господарської діяльності» від 11 вересня 2003 р. № 1160-IV (далі - Закон про регуляторну політику) [12] Національний банк України є регуляторним органом, що приймає регуляторні акти - нормативно-правові акти, які або окремі положення яких спрямовані на правове регулювання господарських відносин, а також адміністративних відносин між регуляторними органами або іншими органами державної влади та суб'єктами господарювання.

У ст. 3 Закону про регуляторну політику передбачено, що дія цього закону поширюється на здійснення регуляторної діяльності, пов'язаної з прийняттям нормативно-правових актів Національного банку України, які спрямовані на виконання ним функцій, визначених зокрема п. 4 ст. 7 Закону України «Про Національний банк України» та мають ознаки регуляторного акта.

Крім того, Національний банк України, керуючись п. 4 ст. 7 Закону України «Про банки та банківську діяльність» від 07 грудня 2000 р. № 2121-III [13], встановлює для банків правила проведення банківських операцій, бухгалтерського обліку та звітності, захисту інформації, коштів та майна.

Висновки. Оскільки на цей час $є$ досить багато фізичних та юридичних осіб, до яких застосовуються персональні спеціальні економічні та інші обмежувальні 
заходи (санкції), та які є боржниками, щодо яких існує необхідність здійснення примусового виконання рішень судів відповідно до Закону, досить необхідним $є$ нормативне врегулювання механізму здійснення звернення стягнення на кошти боржників згідно зі ст. 48 Закону України «Про виконавче провадження», а банківським установам здійснювати списання грошових коштів відповідно до ст. 1072 Цивільного кодексу України, до яких застосовуються персональні спеціальні економічні та інші обмежувальні заходи (санкції).

Згідно зі ст. 1291 Конституції України [14] суд ухвалює рішення іменем України. Судове рішення є обов'язковим до виконання. Держава забезпечує виконання судового рішення у визначеному законом порядку. Контроль за виконанням судового рішення здійснює суд.

У ст. 8 Конституції України передбачено, що в Україні визнається та діє принцип верховенства права. Конституція України має найвищу юридичну силу. Закони та інші нормативно-правові акти приймаються на основі Конституції України та повинні відповідати їй [14].

Таким чином, відсутність механізму врегулювання порушеного питання призводить до невиконання значної кількості судових рішень, що відповідно до Конституції України є обов'язковими до виконання.

В Україні, де визнається верховенство права (ст. 8 Конституції України) судові рішення не можуть бути невиконаними на шкоду одній зі сторін. Відповідно, виконанню судового рішення не можна перешкоджати, відмовляти у виконанні або надмірно його затримувати. Держава зобов' язана організовувати систему виконання судових рішень, яка буде ефективною як за законодавством, так та на практиці, оскільки саме на державу покладається обов'язок вжиття у межах її компетенції усіх необхідних кроків для того, щоб виконати остаточне рішення суду та, діючи таким чином, забезпечити ефективне залучення всього її апарату.

Зазначене кореспондується із позицією Європейського суду з прав людини у справі «Глоба проти України» № 15729/07 від 05.07.2012.

Відтак, розв'язання питання щодо визначення механізму звернення стягнення на кошти боржників згідно зі ст. 48 Закону України «Про виконавче провадження», а банківським установам здійснювати списання грошових коштів відповідно до ст. 1072 Цивільного кодексу України, що стосується боржників, до яких застосовуються персональні спеціальні економічні та інші обмежувальні заходи (санкції), повинно бути пріоритетним для відповідних державних органів.

\section{Iimepamypa:}

1. Про виконавче провадження : Закон України від 02 червня 2016 р. № 1404-VIII (станом на 22 листопада 2018 р.) / Верховна Рада України. Офіційний вісник України. 2019. № 2.

2. Цивільний кодекс України : від 16 січня 2003 р. № 435-IV (станом на 23 листопада 2018 р.) / Верховна Рада України. Голос України. 2018. 12. 12.12.2018. № 237-238.

3. Про санкції : Закон України від 14 серпня 2014 р. № 1644-VII (станом на 09 листопада 2017 р.) / Верховна Рада України. Урядовий кур’єр. 2017. 12. 19.12.2017. № 239.

4. Про рішення Ради національної безпеки та оборони України від 15 березня 2017 р. «Про застосування персональних спеціальних економічних та інших обмежувальних заходів (санкцій)» : Указ Президента України від 15 березня 2017 р. № 63/2017 / Президент України. Офіційний вісник Украӥни. 2017. № 25 (28.03.2017). Ст. 720. 
5. Про рішення Ради національної безпеки та оборони України від 28 квітня 2017 р. «Про застосування персональних спеціальних економічних та інших обмежувальних заходів (санкцій)» : Указ Президента України від 15 травня 2017 р. № 133/2017 / Президент України. Урядовий кур’єр. 2017. 05. 17.05.2017. № 89 .

6. Про рішення Ради національної безпеки та оборони України від 1 березня 2018 р. «Про застосування персональних спеціальних економічних та інших обмежувальних заходів (санкцій)» : Указ Президента від 06 березня 2018 р. № 57/2018 / Президент України. Урядовий кур’єр. 2018. 03. 07.03.2018. № 46.

7. Про рішення Ради національної безпеки та оборони України від 2 травня 2018 р. «Про застосування та скасування персональних спеціальних економічних та інших обмежувальних заходів (санкцій)» : Указ Президента України від 14 травня 2018 р. № 126/2018 / Президент України. Офіційний вісник України. 2018. № 43 (05.06.2018). Ст. 1527.

8. Про рішення Ради національної безпеки та оборони України від 21 червня 2018 р. «Про застосування та внесення змін до персональних спеціальних економічних та інших обмежувальних заходів (санкцій)» : Указ Президента України від 21 червня 2018 р. № 176/2018 / Президент України. Голос України. 2018. 06. 23.06.2018. № 115.

9. Про забезпечення реалізації та моніторингу ефективності персональних спеціальних економічних та інших обмежувальних заходів (санкцій) : Постанова Правління Національного банку України від 01 жовтня 2015 р. № 654 (станом на 03 липня 2018 р.) / Національний банк України. Офіиійний вісник України. 2018. № 65 (28.08.2018). Ст. 2207.

10. Про затвердження Положення про Міністерство юстиції України : Постанова Кабінету Міністрів України від 02 липня 2014 р. № 228 (станом на 26 липня 2018 р.) / Кабінет Міністрів України. Офіиійний вісник України. 2018. № 62 (14.08.2018). Ст. 2145.

11. Про національний банк України : Закон України від 20 травня 1999 р. № 679-XIV (станом на 6 грудня 2018 р.) / Верховна Рада України. Голос України. 2019. 01. 11.01.2019. № 6.

12. Про засади державної регуляторної політики у сфері господарської діяльності : Закон України від 11 вересня 2003 р. № 1160-IV (станом на 22 вересня 2016 р.) / Верховна Рада України. Офіційний вісник України. 2016. № 94 (06.12.2016). Ст. 3068.

13. Про банки та банківську діяльність : Закон України: від 07 грудня 2000 р. № 2121-III (станом 22 листопада 2018 р.) / Верховна Рада України. Голос України. 2018. 12. 26.12.2018. № 248.

14. Конституція України : Закон України від 28 червня 1996 р. № 254к/96-ВР (станом на 02 червня 2016 р.) // Верховна Рада України. Офіиійний вісник України. 2016. № 51 (08.07.2016). Ст. 1799.

\section{Анотація}

Алексєєва О. С. Проблемні аспекти примусового виконання судових рішень та рішень інших органів (посадових осіб) щодо боржників, до яких застосовуються персональні спеціальні економічні та інші обмежувальні заходи (санкції). - Стаття.

У статті досліджено законодавство, що регулює відносини стосовно примусового виконання судових рішень та рішень інших органів (посадових осіб) щодо боржників, до яких застосовуються персональні спеціальні економічні та інші обмежувальні заходи (санкції), досліджено проблемні аспекти примусового виконання судових рішень та рішень інших органів (посадових осіб) щодо боржників, до яких застосовуються персональні спеціальні економічні та інші обмежувальні заходи (санкціі). Акцентовано увагу на тому, що відсутність механізму врегулювання порушеного питання призводить до невиконання значної кількості судових рішень, що відповідно до Конституції України є обов’язковими до виконання.

Ключові слова: виконавчі документи, порядок проведення виконавчого провадження, заходи примусового виконання рішень, строк пред’явлення виконавчого документа до виконання, стягнення за виконавчими документами, черговість списання грошових коштів, персональні спеціальні економічні та інші обмежувальні заходи (санкції).

\section{Аннотация}

Алексеев $\boldsymbol{E} . \boldsymbol{E}$. Проблемные аспекты принудительного исполнения судебных решений и решений других органов (должностных лиц) в отношении должников, к которым применяются персональные специальные экономические и другие ограничительные меры (санкции). - Статья.

В статье исследовано законодательство, регулирующее отношения в отношении принудительного исполнения судебных решений и решений других органов (должностных лиц) к должникам, к которым применяются персональные специальные экономические и другие ограничительные меры (санкции), 
исследованы проблемные аспекты принудительного исполнения судебных решений и решений других органов (должностных лиц) к должникам, к которым применяются персональные специальные экономические и другие ограничительные меры (санкции). Акцентировано внимание на том, что отсутствие механизма урегулирования данного вопроса приводит к невыполнению значительного количества судебных решений, которые согласно Конституции Украины являются обязательными к исполнению.

Ключевые слова: исполнительные документы, порядок проведения исполнительного производства, меры принудительного исполнения решений, срок предъявления исполнительного документа к исполнению, взыскание по исполнительным документам, очередность списания денежных средств, персональные специальные экономические и другие ограничительные меры (санкции).

\section{Summary}

Aleksieieva O. Ye. Complicated aspects of the enforcement of court judgments and decisions of other bodies (officials) concerning the debtors who are subject to personal special economic and other restrictive policy measures (sanctions). - Article.

The article deals with the legislation regulating relations with regard to the enforcement of court judgments and decisions of other bodies (officials) concerning the debtors to whom personal special economic and other restrictive measures (sanctions) are applied. The problematic aspects of the enforcement of court judgments and decisions of other bodies (officials) regarding the debtors who are subject to personal special economic and other restrictive measures (sanctions), are investigated

The emphasis is placed on the fact that the absence of a mechanism for resolving the issue raised leads to a failure to abide by a large number of court judgments, which, in accordance with the Constitution of Ukraine, are binding.

Key words: enforcement documents, procedure for carrying out enforcement proceedings, measures for the enforcement of decisions, time for presentation of an enforcement document to execution, recovery on the basis of enforcement documents, order of writing off the funds, personal special economic and other restrictive measures (sanctions). 